\title{
Investigation of Properties of Medicinal Plants Thyme and Cichorium intybus $L$
}

\author{
Jamal Ahmad, Umar Yusuf*, Musa Muhammad \\ Department of Pharmacology and Therapeutics, College of Health Sciences, Usmanu Danfodiyo University, Sokoto, \\ Nigeria
}

\author{
*Corresponding Author \\ Umar Yusuf
}

\section{Article History}

Received: 26.02 .2020

Accepted: 04.03.2020

Published: 08.03.2020

\begin{abstract}
For thousands of years, medicinal plants have been used to treat various diseases. Traditional medicine is still popular among people today and many people use the properties of medicinal plants to treat diseases. Some herbs are better known than others, both fresh and dried. In this article, we will investigate the properties of some medicinal plants.

Keywords: Medicinal Plants, antibacterial effects, Thyme, Cichorium intybus L.
\end{abstract}

\section{INTRODUCTION}

One of the concerns and concerns in the biomedical and medical sciences is bacterial and fungal resistance to the extent that some of these bacteria are resistant to chemical drugs more than $90 \%$. Alexander Fleming, a well-known biologist and botanist, first examined the bacterial resistance and won the Nobel Prize in 1945 [1-3]. Nowadays, in cases where drug resistance is created by changing the drug to fight against pathogenic bacteria and fungi. On the other hand, for many years, natural remedies, especially medicinal herbs, have been the basis and even in some cases the only treatment, while their raw materials have been used in the pharmaceutical industry [4]. The advent of chemistry in the early twentieth century and the development of complex organic synthesis systems led to the development of the pharmaceutical industry and the substitution of synthetic drugs for herbal remedies [5]. But as advances in the production of new chemicals and various antibiotics began to take place, the harmful effects of these drugs gradually began to appear, and since the 1950s numerous pathogenic bacteria have shown resistance to antibiotics, which is still expanding [6]. Medicinal plants worldwide are used by indigenous populations and play an important role in treating human and animal diseases [7]. One of the major problems in antibiotic therapy today is the resistance and subsequent side effects of the drug. Accordingly, after researching the effects of plants, man has used them in various industries [8]. After the discovery of penicillin in the 40s, and its use in treatment, new antibiotics were introduced every day to treat infections [9]. The result was the expansion of the clinical use of natural and synthetic antibiotics in the treatment of clinical infections [10]. The overuse of these antimicrobial drugs has led to increased drug resistance against different antibiotics in most bacteria [11-13]. This has been one of the reasons for the growing use of herbs as low-risk, affordable, and inexpensive natural ingredients in the treatment of bacterial infections compared to synthetic antibiotics [14-16]. Also, these herbal remedies are more popular with people [17-19]. The role of natural products in drug production is increasing, not only when bioactive compounds are used directly as therapeutic drugs, but also when used as a raw material for drug synthesis, or as a model the base is used for new biologically active compounds [20-22]. Studies show that only about $10 \%$ of the 250,000 species of plants studied worldwide [23]. Therefore, the use of herbal drugs as an alternative to chemical drugs and antibiotics was investigated.

\section{Thyme}

Thyme is one of the most popular medicinal herbs that has long been used to treat a variety of diseases. This herb has aromatic and medicinal properties in the food, pharmaceutical, health and beauty industries. Thyme is useful for the treatment of headaches, colds, earaches, measles, cough, nerve strengthening, treatment of depression, fatigue and insomnia, and its use reduces blood pressure and lipids [24, 25]. It is also an anticonvulsant, antiepileptic and anti-

Copyright @ 2020: This is an open-access article distributed under the terms of the Creative Commons Attribution license which permits unrestricted use, distribution, and reproduction in any medium for non commercial use (NonCommercial, or CC-BY-NC) provided the original author and source are credited. 
bloating medicinal product that enhances eyesight and stomach. Thinning with Thyme helps to heal and reduce hair loss. Eating thyme after meals treats any gastrointestinal problems such as bloating, heaviness, and stomach cramps [26, 27]. Thyme counteracts respiratory tract infections and reduces cough. The most effective antimicrobial compound is thymol and carvacrol [28]. Based on previous studies, it has been shown that Thyme extract can inhibit the growth of Escherichia coli, Salmonella, Shigella, Staphylococcus aureus, Klebsiella, Enterococcus, Pseudomonas aeruginosa and Acinetobacter spp [29-36].

\section{Cichorium Intybus $L$.}

Cichorium intybus is a medicinal plant with blue or purple flowers that is quite cool, a liver booster, and a heat and thirst pain reliever, and a warmth and booster for kidney and blood pressure, bile and urinary tract and kidney cleansers [37]. Water consumption of Cichorium intybus leaves is a useful medication for treating jaundice, kidneys and liver and relieves fever and strengthens the stomach [38]. Cichorium intybus is used to regulate blood pressure, lower blood sugar and treat headaches and liver diseases. It is used to relieve hot swelling, eye pain and visual acuity [39]. The Cichorium intybus root is warm and dry, and softening the chest, and consuming 2 cups of chicory leaf and a boiled root is very useful in the treatment of constipation. Given the presence of trypenoids in Cichorium intybus, these compounds may exert their antimicrobial and antifungal activity through binding to proteins and altering their function [40].

\section{CONCLUSION}

Rosemary significantly reduces the growth of disease-causing bacteria and slows the growth of bacteria, which increases with increasing concentration of these properties. Given the importance of medicinal plants and their derived metabolites in ensuring the health of human communities and the high economic potential of these plants, as a reliable source of income, a comprehensive and comprehensive plan is needed in developing countries. Part of the agricultural biotechnology research at universities and research institutes is dedicated to identifying, industrializing and optimizing the methods of extracting pharmaceutical metabolites from these plants.

\section{REFERENCES}

1. Cragg, G. M., \& Newman, D. J. (2013). Natural products: a continuing source of novel drug leads. Biochimica et Biophysica Acta (BBA)-General Subjects, 1830(6), 3670-3695.

2. Mukherjee, P. K., Satheesh Kumar, N., \& Heinrich, M. (2008). Plant made pharmaceuticals (PMPs)-development of natural health products from bio-diversity. Indian Journal of Pharmaceutical Education and Research, $42(2), 113$.

3. Jardak, M., Elloumi-Mseddi, J., Aifa, S., \& Mnif, S. (2017). Chemical composition, anti-biofilm activity and potential cytotoxic effect on cancer cells of Rosmarinus officinalis L. essential oil from Tunisia. Lipids in health and disease, 16(1), 190.

4. Jafari-Sales, A., Jafari, B., Sayyahi, J., \& Zohoori-Bonab, T. (2015). Evaluation of antibacterial activity of ethanolic extract of malva neglecta and althaea officinalis 1 . On antibiotic-resistant strains of staphylococcus aureus. $J$ Biol Today World, 4(2), 58-62.

5. Gulluce, M., Sahin, F., Sokmen, M., Ozer, H., Daferera, D., Sokmen, A., ... \& Ozkan, H. (2007). Antimicrobial and antioxidant properties of the essential oils and methanol extract from Mentha longifolia L. ssp. longifolia. Food chemistry, 103(4), 1449-1456.

6. Jafari-Sales, A., Shahniani, A., Fathi, R., Malekzadeh, P., Mobaiyen, H., \& Bonab, F. R. (2017). Evaluation of Antibacterial Activity of Essential Oil of Ziziphora clinopodioides and Achillea wilhelmsii on Antibiotic-resistant Strains of Staphylococcus aureus. Internal Medicine and Medical Investigation Journal, 2(2), 49-56.

7. Zainab, A., Bhat, R., Acharya, S., Yende, A., PS, P., \& Padyana, S. (2013). Studies on antioxidant and antimicrobial activities of Pajanelia longifolia (Willd.) Schumann. Obesity Research Journal. DOI, 10(2013.756484).

8. Sales, A. J., Shadbad, N. N., \& Kaleybar, V. P. (2015). The Investigation of the Antibacterial effects of Ethanol extract of Cichorium intybus L. on Antibiotic-resistant Staphylococcus aureus strains. Bull Env Pharmacol Life Sci, 4, 161-164.

9. Mobaiyen, H., Jafari Sales, A., \& Sayyahi, J. (2016). Evaluating antimicrobial effects of centaurea plant's essential oil on pathogenic bacteria: staphylococcus aureus, staphylococcus epidermidis, and escherichia coli isolated from clinical specimens. Journal of Fasa University of Medical Sciences, 5(4), 479-487.

10. Tunç, K., Hos, A., \& Gunes, B. (2013). Investigation of antibacterial properties of Cotinus coggygria from Turkey. Pol. J. Environ. Stud, 22(5), 1559-1561.

11. Jafari-Sales, A., \& Bolouri, P. (2018). Evaluation of the antimicrobial effects of Glycyrrhiza glabra 1. on some gram positive and gram negative pathogenic bacteria in laboratory conditions. $\quad \square \square \square \square \quad \square \square \square \square \quad \square \square \square$ $\square \square \square \square \square, 6(4), 78-84$.

12. Cowan, M. M. (1999). Plant products as antimicrobial agents. Clinical microbiology reviews, 12(4), 564-582.

13. Sales, A. J., Malekzadeh, P., Ebrahimzadeh, M., Kondlaji, K. B., Kaleybar, V. P., \& Dizaji, A. S. (2015). Evaluation of the anti-bacterial effects of ethanolic extract of yarrow (Achillea wilhelmsii) on antibiotic-resistant strains of Staphylococcus aureus. Journal home page: http://www. journalsci. com ISSN, 2322, 326X. 
14. Sales, A., Bagherizadeh, Y., Malekzadeh, P., Ahmadi, B., \& Bonab, F. R. (2017). Evaluation of the antimicrobial effects of essential oil of Reseda Lutea L. on pathogenic bacteria: Staphylococcus aureus, Staphylococcus Epidermidis, and Escherichia coli. Arch Clin Microbiol, 8(3), 1-6.

15. İşcan, G., Kirimer, N., Kürkcüoğlu, M., Başer, H. C., \& DEMIrci, F. (2002). Antimicrobial screening of Mentha piperita essential oils. Journal of agricultural and food chemistry, 50(14), 3943-3946.

16. Jafari-Sales, A., \& Hossein-Nezhad, P. (2019). Antimicrobial effects of Rosmarinus officinalis methanolic extract on Staphylococcus aureus, Bacillus cereus, Escherichia coli and Pseudomonas aeruginosa in laboratory conditions. Journal of Medicinal and Chemical Sciences, 103-108.

17. Sales, A. J. (2014). Evaluation of antibacterial activity of ethanol extract of Lavandula Stoechas L. plant on antibiotic-resistant strains Of Staphylococcus Aureus. Journal of Current Research in Science, 2(6), 641.

18. Mahboubi, M., \& Haghi, G. (2008). Antimicrobial activity and chemical composition of Mentha pulegium L. essential oil. Journal of ethnopharmacology, 119(2), 325-327.

19. Jafari-Sales, A., Rasi-Bonab, F., \& Sayyahi, J. (2019). The Survey on Antimicrobial Effects of Methanolic Extract of Carum Copticum L. on Staphylococcus Aureus, Bacillus Cereus, Escherichia Coli and Pseudomonas Aeruginosa in Laboratory Conditions. Paramedical Sciences and Military Health, 13(4), 19-25.

20. Jafari-sales, A., \& Shadi-Dizaji, A. (2019). Evaluation of Inhibitory Effect of Methanol Extract of Allium Sativum in vitro on Staphylococcus aureus and Escherichia coli. Scientific Journal of Nursing, Midwifery and Paramedical Faculty, 5(1), 61-68.

21. Tajehmiri, A., Issapour, F., Moslem, M. N., Lakeh, M. T., \& Kolavani, M. H. (2014). In vitro antimicrobial activity of Artemisia annua leaf extracts against pathogenic bacteria. Adv Stud Biol, 6, 93-97.

22. Jafari-Sales, A., Hossein-Nezhad, P., \& Bolouri, P. (2019). Identification of chemical composition of essential oil and evaluation of antimicrobial effects of ethanolic extract of Mentha pulegium on Staphylococcus aureus and Escherichia coli. Health Biotechnology and Biopharma, 3, 29-38.

23. Jafari-Sales, A., Mobaiyen, H., Jafari, B., \& Sayyahi, J. (2019). Assessment of Antibacterial Effect of Alcoholic Extract of Centaurea depressa MB, Reseda lutea L. and Fumaria asepala on Selected Standard Strains in Vitro. Scientific Journal of Nursing, Midwifery and Paramedical Faculty, 5(3), 63-73.

24. Aghel, N., Moghimipour, E., \& AMERI, A. G. (2007). Characterization of an anti-dermatophyte cream from Zataria multiflora Boiss. Iranian Journal Pharm Science, 3:77-84.

25. Hemaiswarya, S., Kruthiventi, A. K., \& Doble, M. (2008). Synergism between natural products and antibiotics against infectious diseases. Phytomedicine, 15(8), 639-652.

26. Fu, Y., Zu, Y., Chen, L., Shi, X., Wang, Z., Sun, S., \& Efferth, T. (2007). Antimicrobial activity of clove and rosemary essential oils alone and in combination. Phytotherapy research, 21(10), 989-994.

27. Moreno, S., Scheyer, T., Romano, C. S., \& Vojnov, A. A. (2006). Antioxidant and antimicrobial activities of rosemary extracts linked to their polyphenol composition. Free radical research, 40(2), 223-231.

28. Bagamboula, C. F., Uyttendaele, M., \& Debevere, J. (2004). Inhibitory effect of thyme and basil essential oils, carvacrol, thymol, estragol, linalool and p-cymene towards Shigella sonnei and S. flexneri. Food microbiology, 21(1), 33-42.

29. Shafiee, A., \& Javidnia, K. (1997). Composition of essential oil of Zataria multiflora. Planta medica, 63(04), 371372 .

30. Fazlara, A., Najafzadeh, H., \& Lak, E. (2008). The potential application of plant essential oils as natural preservatives against Escherichia coli O157: H7. Pak J Biol Sci, 11(17), 2054-61.

31. Fazeli, M. R., Amin, G., Attari, M. M. A., Ashtiani, H., Jamalifar, H., \& Samadi, N. (2007). Antimicrobial activities of Iranian sumac and avishan-e shirazi (Zataria multiflora) against some food-borne bacteria. Food control, 18(6), 646-649.

32. Mayrhofer, S., Paulsen, P., Smulders, F. J., \& Hilbert, F. (2004). Antimicrobial resistance profile of five major food-borne pathogens isolated from beef, pork and poultry. International journal of food microbiology, 97(1), 2329.

33. Abbasgholizadeh, N., Ettehad, G., \& Arab, R. (2008). Antibacterial effects of Zataria multiflora Boiss (Shiraz organo essence) on Enterobacteriaceae species. Research Journal Biological Science, 3:345-347.

34. Shokri, H., Asadi, F., Bahonar, A. R., \& Khosravi, A. R. (2006). The role of Zataria multiflora essence (Iranian herb) on innate immunity of animal model. Iranian Journal of Immunology, 3(4), 164-168.

35. Motevasel, M., Zomorodian, K., Mansouri, A., Farshad, S. H., Haghighhat, A. R., Hadaegh, M. G., \& Takhshid, M. A. (2011). The anti-bacterial effects of Zataria multiflora extract on common pathogenic Gram positive cocci, pathogenic Gram negative bacilli and non-pathogenic bacteria. African Journal of Microbiology Research, 5(28), 4993-4996.

36. Mir, N., Sánchez, M., Baquero, F., López, B., Calderón, C., \& Cantón, R. (1998). Soft salt-mannitol agarcloxacillin test: a highly specific bedside screening test for detection of colonization with methicillin-resistant Staphylococcus aureus. Journal of clinical microbiology, 36(4), 986-989. 
37. Shad, M. A., Nawaz, H., Rehman, T., \& Ikram, N. (2013). Determination of some biochemicals, phytochemicals and antioxidant properties of different parts of Cichorium intybus L.: A comparative study. J Anim Plant Sci, 23(4), 1060-1066.

38. Gheisari, H. R., Habibi, H., Khadem, A., Anbari, S., \& Khadem, A. A. (2016). Comparison of Antimicrobial activity of Cichorium intybus, Dorema aucheri and Prangos ferulacea extracts against some food borne pathogens. International Journal of Pharmaceutical Research and Allied Sciences, 5(3), 80-4.

39. Verma, R., Rawat, A., Ganie, S. A., Agnihotri, R. K., Sharma, R., Mahajan, S., \& Gupta, A. (2013). In vitro antibacterial activity of Cichorium intybus against some pathogenic bacteria. Journal of Pharmaceutical Research International, 767-775.

40. Seca, A. M., Grigore, A., Pinto, D. C., \& Silva, A. M. (2014). The genus Inula and their metabolites: from ethnopharmacological to medicinal uses. Journal of ethnopharmacology, 154(2), 286-310. 